ROMAN HRUŠKA, Ing. Ph.D. ${ }^{1}$

(Corresponding author)

E-mail: roman.hruska@upce.cz

MATEJ KMETÍK, Ing. ${ }^{1}$

E-mail: matej.kmetik@student.upce.cz

JAN CHOCHOLÁČ, Ing. Ph.D. ${ }^{1}$

E-mail: jan.chocholac@upce.cz

${ }^{1}$ University of Pardubice

Faculty of Transport Engineering

Department of Transport Management,

Marketing and Logistics

Studentská 95, 53210 Pardubice, Czech Republic
Transport Logistics Original Scientific Paper Submitted: 30 June 2021 Accepted: 20 Oct. 2021

\title{
SELECTION OF THE TRANSPORT MODE USING THE AHP METHOD WITHIN DISTRIBUTION LOGISTICS OF MOTOR FUELS
}

\begin{abstract}
To remain competitive and respond to rapidly changing markets, we need to increase flexibility in today's global marketplace. In this respect, the selection of the appropriate mode of transport is one of the most important functions to be performed by logistics. The selection of the appropriate mode of transport is a multi-criteria problem involving both quantitative and qualitative criteria. This paper deals with the selection of the mode of transport using the Analytic Hierarchy Process method (AHP). AHP is a method of decomposing a complex unstructured situation into simpler components to create a hierarchical system problem. This paper describes a general model of selection of transport mode using AHP including its application to a manufacturing company that selects the appropriate mode of transport from three potential transport modes. The aim of this paper is to create a useful decision support tool for selection of the transport mode using the AHP method within distribution logistics of motor fuels. This tool helps companies to make the right decision on the choice of transport mode by taking into account different importance of the different criteria that influence the decision-making process.
\end{abstract}

\section{KEYWORDS}

transportation; distribution logistics; AHP method; Saaty method; decision-making; transport mode.

\section{INTRODUCTION}

Selecting the appropriate mode of transport within the distribution logistics is a priority for most companies in various business sectors. The goal of the companies is to optimise costs but also other distribution parameters. Due to these facts, this issue is a complex logistic decision-making problem. Motor fuel transport companies must guarantee their delivery at the right time, in the right place, in the right quality, with the right information, and at a right cost. Motor fuels are usually transported by the following modes of transport: road, rail, water, and pipeline or combined. The topicality of this issue is confirmed by the fact that the selection of a suitable mode of transport has gained great importance in the management of entire supply chains due to globalisation, reducing negative environmental impacts, increasing added value, and technological changes. The ongoing globalisation of markets over the past decades accounts for an ever-increasing shipping volume of goods worldwide; in all industries, companies operate facilities spread across the world to maximise profitability, and procurement and distribution have become global operations [1]. The change of people's way of life over time has resulted, in a relatively short period, in a great increase of the need for distribution of goods [2].

The increase in consumption entails the development of production, thus increasing the demand for transport services, which implies the deepening of transport problems such as pollution, congestion, waste production, road accidents, or the intensive use of fossil fuels [3]. Logistics is the set of services and activities that allow goods to be carried from the place of origin in which they are available to the destinations where they are required, and transport helps to connect the sources of raw materials, 
production centres, and markets [4]. The logistics industry is a critical economic component in most countries and has a significant impact on their citizens' quality of life [5]. Freight transport is a key element in the economic development of countries too; nevertheless, the complexity and heterogeneity involved in the carriage of goods makes it much more difficult to analyse and solve than passenger transport [6]. The management of freight transportation flows involves many elements, including producers, traders, distributors, logistic companies, storage companies, transportation companies, authorities, and ultimately consumers [7,8].

Distribution logistics within the refining industry is very strongly specific, which implies that companies pay significant attention to it. There are several main reasons for this. Products of the refining industry belong to the category of dangerous goods. The transports are carried out using road freight transport according to the ADR (Accord européen relatif au transport international des marchandises Dangereuses par Route) agreement, using rail freight transport according to the RID (Règlement concernant le transport international ferroviaire des marchandises dangereuses) agreement or using inland waterways according to the ADN (European Agreement concerning the International Carriage of Dangerous Goods by Inland Waterway) agreement. One of the main and fundamental requirements for the transport of refinery products is safety and reliability. Another important specificity is the fact that transports are usually not carried out in the doorto-door mode with only one transport mode, but very often combined transport is used and the first and last miles are usually provided by road freight transport. The presented facts clearly show that decision-making in the field of distribution logistics of the refining industry is a very complex and complicated task with many criteria of varying degrees of influence.

Many scientific articles deal with the issue of distribution logistics and the selection of a suitable transport mode, but none of them is strictly focused on the refining industry, which is so specific that it requires a completely unique approach to this decision-making problem. The weakness of previous research and the identified gap is the non-coverage of the refining industry in the context of distribution logistics and the selection of a suitable transport mode. The main contribution of this article is a literature review in the field of criteria influencing the choice of transport mode within the distribution logistics of motor fuels. The article also contains the proposal of a decision-making tool for selection of the transport mode using the AHP method within distribution logistics of motor fuels. This manuscript is relevant to many stakeholders: primarily for logistic staff in the refining industry, logistic service providers, and transport companies; secondarily mediated to people as a whole in order to reduce negative environmental and social impacts and increase transport safety. The aim of this paper is to create a useful decision support tool for selection of the transport mode using the AHP method within distribution logistics of motor fuels. This tool helps companies to make the right decision on the choice of transport mode by considering the different importance of the different criteria that influence the decision-making process.

\section{LITERATURE REVIEW}

In last years, freight network planning and the application of distribution logistics innovations have become popular fields of research with regards to sustainable logistics [9]. Hugos [10] points out that the costs generated within loads distribution constitute $30 \%$ of the company's operating costs. The comprehensive optimisation of distribution logistics and distribution costs and the simultaneous improvement of service quality provides significant competitive advantages for companies [11]. The complexity of providing timely and cost-effective distribution logistics of finished goods from industrial facilities to customers makes effective operational coordination difficult; on the other side, effectiveness is crucial for maintaining customer service levels and sustaining a business [12]. Recently, there have been efforts to achieve more effective and less polluting freight transportation systems; an advanced system which uses advanced methods to solve vehicle routing and scheduling problems, considering a plethora of constraints has been developed within a research project co-funded by Greece and the European Union [13, 14]. Big companies often plan distribution logistics operations based on their empirical experience, without the use of optimisation methods, because adequate methods or tools, for example for selecting a suitable mode of transport, supplier, etc., are not sufficient [15]. Logistic planning becomes increasingly complex with growing numbers of customers, varied geographical 
locations, the uncertainty of future orders, and sometimes-extreme competitive pressure to reduce costs [12].

Two distinctions are commonly used in the literature for classifying distribution choice freight models. Firstly, there is the distinction between different degrees of multimodality (possibly combined with type and size of shipments) and secondly, the distinction between different levels of aggregation [16]. The first distinction is connected to the detailing of the endogenous variable; models that study the mode choice for each origin-destination relation separately without considering that this origin-destination relation could be part of a larger, multimodal transport chain $[16,17]$. Some of the models not only explain mode or transport chain selection, but other choices as well, such as shipment size [18], supplier choice [19], and route choice [20]. The second distinction between different levels of aggregation is relevant for estimation as well as for application [16], and there are two approaches: disaggregate mode choice or transport choice models [21] and aggregate mode choice models [22].

Guo et al. [23] stated that the problem of transport mode selection within distribution logistic planning exists in some manufacturing supply chains; there are multiple transport modes available for transportation, each of which represents a type of vehicles with a certain transport time and a certain carrying capacity. According to the authors, the manufacturer needs to decide when to pick up the finished products and which transport mode is selected for each delivery order, which is a complex decision-making task. Traditionally, the decision for a distribution mode selection has been based on the lead time and transport cost trade-off, i.e. the longer the lead time, the higher the inventory required to deal with demand uncertainty, and the lower the transport cost; however, over time, other criteria have been added, such as greenhouse gas emissions, transport safety, and number of transshipments [24]. Many scientific articles show the consideration of transport energy consumption and transition from high-energy transport modes (such as air and road transport) to low-energy transport modes (such as railway transport) $[25,26]$. Keya et al. [27] identified the following categories of exogenous variables that influence distribution mode choice: level of service measures (such as shipping time, shipping cost, speed, delay, fuel cost), freight characteristics (such as commodity group, commodity size, commod- ity density, commodity value, commodity weight, product state, temperature controlled or not, perishability, trade type, quantity), transportation network and origin-destination attributes (such as shipment origin-destination, distance, ratio of highway and railway miles in origin and in destination), and others (such as service reliability, service frequency, loss and damage, shipper's characteristics).

Another area of not only scientific but also practical interest is the area of selection, evaluation or management of suppliers, which is discussed among authors from all industries. Kagnicioglu [28] believes that supplier selection and related transport mode selection is a critical purchasing management activity in the supply chain due to the key role of supplier performance in terms of cost, quality of supply, and services in achieving supply chain objectives. Effective supplier management, which begins with the identification of potential suppliers, is paramount to a successful supply chain management [29]. Selecting the right supplier also significantly reduces purchasing costs and improves the company's competitiveness [30]. Lin [31] believes that selecting suppliers to reduce the supply base is an important goal in supply chain management. Some authors are concerned with selecting appropriate performance metrics to help select and evaluate suppliers. Huang and Keskar [32] argue that cost and quality are the most dominant factors along with timely delivery and flexibility. Hsu et al. [33] developed and verified the design of supplier selection and demonstrated that the quality and capabilities of supplier services need to be assessed based on documented supplier selection criteria. Kannan and Tan [34] consider quality, price, response and additional services to be important criteria for supplier selection. Another approach deals with supplier evaluation methods for a given set of performance metrics [35]. Lasch and Janker [29] designed a supplier evaluation system that uses the analysis of basic components to create a classification and order of potential suppliers using ellipsoidal clusters. Huang and Keskar [32] and Barbarosoglu and Yazgac [36] used an AHP to select suppliers. The supplier selection issue can also be considered part of the optimisation problem. Kagnicioglu [28] proposed a fuzzy multipurpose model in which the goals and some limitations are fuzzy to consider many conflicting and unclear goals and limitations when deciding on the choice of supplier. Morlacchi [37] developed a model that combines the application of fuzzy 
set theory with AHP and implements it to evaluate small suppliers in the engineering industry. Kumar, Vrat and Shankar [38] used fuzzy programming of goals; they solved the impact of information uncertainty on problems with the supplier's selection. Ghodsypour and O'Brien [30] used the integrated AHP model to reduce the number of suppliers (alternatively transport modes).

The problem of transport mode selection within distribution logistic planning is a very complex and complicated decision-making problem with many criteria of varying degrees of influence. Kumru and Kumru [39] defined these criteria as follows: cost, speed, safety, accessibility, reliability, environmental friendliness, and flexibility of transportation. Shen et al. [40] emphasised these criteria: reliability during transport, capacity, quality of service, transportation quickness, and flexibility of operation. Ozcan and Ahiskali [41] summarised these criteria on the basis of a literature search e.g. delay rate, error rate, documentability, service quality, service ability, green policy, and operation excellence. The following authors have defined the following criteria in relation to the decision-making problem: flexibility, reliability, speed, traceability, costs, security problems, risk [42]; economic features, service features, costs, traceability, environmental impacts, reliability, flexibility, speed [43]; transport distance, transport time, transport cost [44]; cost, time, reliability, power requirement, accessibility, product protection [45]; transport distance, transport time, transport cost, transport service, security, awareness [46]; transport time, cost, reliability, security [47]; transportation time, transportation cost, reliability, route properties, storage cost [48]; transport cost, shipping time, delivery time, supply price, cost [49]; service quality, reliability, transportation policy, economic and environmental impacts [50].

This paper deals with the process of objective selection of the transport mode for a specific transport requirement, which can be achieved using the AHP method. This method provides a framework for effective logistic decision-making in complex and difficult decision-making tasks and helps to simplify and speed up the natural decision-making process.

\section{PROPOSED MODEL}

The selection of a suitable transport mode for the company within the distribution logistics is a logistic decision-making problem that can be solved us- ing the AHP method. This is also confirmed by the processing of literature review. The AHP method is a systematic approach that can be used to select the appropriate mode of transport but also to other decision-making tasks. In general, there is a problem that people have to make decisions on complex problems with many input qualitative and quantitative variables. It is very difficult to make the right decision for these problems. The AHP method makes it easier for people to make the right decision that reflects the relevant criteria for a given decision problem. The AHP method was developed by Saaty [51] and has been continuously improved ever since. AHP is a method of deciding on the preference of alternatives in a situation where more criteria need to be considered. Another reason why the AHP method was chosen is that it is based on Saaty's method. Saaty's method is based on pairwise comparison and allows using the Saaty's scale (Equation 3) to express the degree of preferences between criteria and alternatives (in this case transport modes). One of the main advantages of the AHP method is its simplicity of implementation in decision-making processes. As a result, the AHP method allows the decision-maker to solve complex problems in the form of a hierarchy or a set of integrated levels. The AHP method is usually based on a hierarchy of at least three levels: goal, criteria, and alternatives. In case of a problem with the selection of the most suitable transport mode within the distribution logistics, the aim is to select the most suitable transport mode for a specific transport. Criteria can be cost, quality, safety, additional services, delivery time, etc. on the basis of processed literature review. Another possibility is to identify the criteria using the brainstorming method from the criteria obtained by the literature review. Brainstorming is one of the techniques for fostering group creativity by which ideas and thoughts are shared among members spontaneously in order to reach solutions to practical problems [52]. Al-Samarraie and Hurmuzan [53] add that brainstorming techniques are delivered in three main ways: verbal/ traditional brainstorming, nominal brainstorming, and electronic brainstorming.

Alternatively, there are different designs of transport modes for a specific transport. The AHP method provides a comprehensive and rational framework for solving this complex problem, including the representation and quantification of individual criteria and their connection to the overall goal, and for the evaluation of alternatives (Figure 1). This 


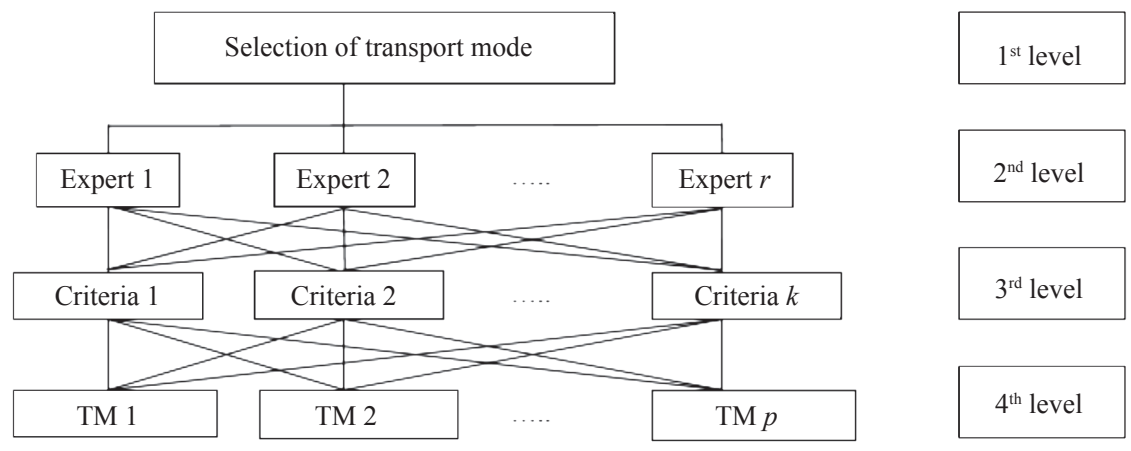

Figure 1 - Hierarchic system of decision problem - selection of transport mode

$(r$-total number of experts, $k$-total number of criteria, $p$ - total number of transport modes, TM-transport mode)

method provides a framework for effective logistic decision-making in complex situations and helps to simplify and speed up the natural decision-making process.

AHP is a method of decomposing a complicated unstructured decision-making problem into simpler components. This creates a hierarchical problem. The AHP method is close to simple methods for determining the value of alternatives, because the overall valuation of alternatives is again determined as a weighted sum of alternatives with respect to the evaluation of individual criteria. The optimal alternative is determined as the best rated alternative. This designation is also used in this manuscript. Saaty's method is used at every level of the hierarchical structure of the solved decision problem. Using the Saaty method, each component of quantitative characteristics reflecting their importance is assigned. The highest priority component is obtained by synthesising these evaluations. The decision maker focuses on it to reach a solution of the decision problem. When solving decision-making problems, more experts are usually used, who evaluate the connection between the goal and individual criteria. Experts can be evaluated by a weight that reflects their expertise or reliability in relation to a given decision problem.

The expertise of experts can be described as a weight vector:

$$
\begin{aligned}
& v^{\text {experts }}=\left(v_{1}, v_{2}, \ldots, v_{r}\right) \\
& \sum_{j=1}^{r} v_{j}=1
\end{aligned}
$$

where:

$v_{1}$ - weight of $1^{\text {st }}$ expert

$v_{r}$ - weight of $r^{\text {th }}$ expert
For the determination weights of criteria, Saaty's method has been chosen. This method takes into account the different preferences between the criteria and a wide point scale is determined for evaluation (Equation 3). It is therefore possible to detect even slight differences in preferences between the criteria, which are then in the process of setting the weights into account.

$$
\left(s_{i j}\right)=\left\{\begin{array}{l}
1-i \text { and } j \text { are equivalent } \\
3-i \text { is mildly preferred to } j \\
5-i \text { is strongly preferred to } j \\
7-i \text { is very strongly preferred to } j \\
9-i \text { is absolutely preferred to } j
\end{array}\right.
$$

Values 2, 4, 6, 8 are intended to evaluate intermediate stages. This method is comparing each pair of criteria $i$ and $j$. Their evaluation is written to the Saaty's matrix (Equation 4) according the following rules:

$$
S=\left(\begin{array}{cccc}
1 & s_{12} & \ldots & s_{1 k} \\
1 / s_{12} & 1 & \ldots & s_{2 k} \\
\ldots & \ldots & \ldots & \ldots \\
1 / s_{1 k} & 1 / s_{2 k} & \ldots & 1
\end{array}\right)
$$

This method involves 5 steps [51], which includes calculation of the weights $v_{i}$ using normalised geometric average (Equations 6-9) of lines Saaty's matrix:

First, Saaty's matrix was filled so that the diagonal values are equal to one $\left(s_{i j}=1\right)$. If the $i^{\text {th }}$ criterion is preferred to $j^{\text {th }}$ criterion, then the appropriate value of Saaty's point scale (Equation 3) has to be selected. If the $j^{\text {th }}$ criterion is preferred to $i^{\text {th }}$ criterion, inverse values have to be written:

$s_{j i}=1 / s_{i j}$ 
For every $i$, the value

$s_{i}=\prod_{j=1}^{k} s_{i j}$

was calculated.

For every $i$, the value

$R_{i}=\sqrt[k]{S_{i}}$

was calculated, where $R$ is the geometric average.

In the next step, the value

$\sum_{i=1}^{k} R_{i}$

was calculated.

In the last step of the method, weights of criteria are determined according to the following Equation 9: $v_{i}=\frac{R_{i}}{\sum_{i=1}^{k} R_{i}}$

Weights of criteria are determined if we multiply all elements for each row and determine the $n^{\text {th }}$ root of this product, when $n$ is the number of elements. Then we standardise the resulting geometric averages of each row of Saaty's matrix (we divide geometric averages of each row by the sum of all geometric averages).

This procedure gives estimate weights of each criterion, which can be written in the form of weight vector:

$v=\left(v_{1}, v_{2}, \ldots, v_{k}\right)$

Saaty's method can be used not only to determine preferences between criteria, but also between variants, using the Analytical Hierarchical Process (AHP).

\subsection{Defining criteria for selection of transport mode}

The manuscript reflects the real complex decision-making situation in a company providing transport of motor fuels, when it is necessary to select the most suitable transport mode for a given transport requirement. First, it is necessary to identify suitable criteria (based on a literature review) influencing this complex decision-making problem. The choice of criteria for the optimal choice of suitable mode of transport was based on the complexity of the system of logistic and production companies, e.g. on the fact that as much infrastructure, functional, technical, technological, and organisational information as possible needs to be included. The aim was to define the most suitable mode of trans- port with the relevant characteristics based on the identified criteria for the proposed model. It is crucial to select a limited number of important criteria, as the large number of criteria makes pairwise comparisons very difficult and time-consuming when evaluating modes of transport. To overcome these problems, a cut-off value for reducing the number of criteria to a few is desirable. List of possible criteria $\left(\mathrm{C}^{\mathrm{TM}}\right)$ based on a literature review is presented in Table 1.

Table 2 shows the matrix of weights assigned to each criterion by $r^{\text {th }}$ experts.

The aggregate weight for each criterion was calculated using the following Equation 11:

$$
w K_{i}^{\mathrm{TM}}=\sum_{j=1}^{r} v_{j} \cdot w_{i j}
$$

where:

$w K_{i}^{\mathrm{TM}}$ - aggregated weight of the $i^{\text {th }}$ criterion for selection of transport mode, $i=1,2, \ldots, k$

$v_{j} \quad-$ weight $j^{\text {th }}$ expert

$j=1,2, \ldots, r$

$w_{i j} \quad-$ weight of the $i^{\text {th }}$ criterion assigned by $j^{\text {th }}$ expert

Aggregated weights of individual criteria for selection of transport mode can be written in the form of aggregated weight vector:

$$
w K^{\mathrm{TM}}=\left(w K_{1}^{\mathrm{TM}}, w K_{2}^{\mathrm{TM}}, \ldots, w K_{k}^{\mathrm{TM}}\right)
$$

Furthermore, $p$ transport modes were compared by Saaty's method for planning each criterion. Table 3 shows the matrix of weights for individual transport modes in terms of each criterion.

Each element $u_{i j}$ of the matrix (Table 3) represents the weight of the $i^{\text {th }}$ transport mode in relation to the $j^{\text {th }}$ criterion. Aggregated weight of each transport mode can be calculated using the following Equation 13:

$w D^{\mathrm{TM}}=\sum_{j=1}^{k} w K_{j}^{\mathrm{TM}} \cdot u_{i j}$

where:

$i=1,2, \ldots, p$

$w D_{i}^{\mathrm{TM}}-$ aggregated weight of the $i^{\text {th }}$ transport mode

$u_{i j} \quad$ - weight of the $i^{\text {th }}$ transport mode in relation to the $j^{\text {th }}$ criterion

Aggregated weights of individual transport modes can be written in the form of aggregated weight vector:

$w D^{\mathrm{TM}}=\left(w D_{1}^{\mathrm{TM}}, w D_{2}^{\mathrm{TM}}, \ldots, w D_{p}^{\mathrm{TM}}\right)$ 
Hruška R, et al. Selection of the Transport Mode Using the AHP Method Within Distribution Logistics of Motor Fuels

Table 1 - List of possible criteria $\left(C^{T M}\right)$ related to the decision-making problem of transport mode selection

\begin{tabular}{|c|c|}
\hline Author(s) & Criteria \\
\hline Guo et al. [23] & transport time, capacity \\
\hline Hoen et al. [24] & lead time, transport cost, greenhouse gas emissions, transport safety, number of transshipments \\
\hline $\begin{array}{l}\text { Blauwens et al. [25], } \\
\text { Kiesmuller et al. [26] }\end{array}$ & transport energy consumption \\
\hline Keya et al. [27] & $\begin{array}{l}\text { level of service measures (such as shipping time, shipping cost, speed, delay, fuel cost), freight } \\
\text { characteristics (such as commodity group, commodity size, commodity density, commodity value, } \\
\text { commodity weight, product state, temperature controlled or not, perishability, trade type, quanti- } \\
\text { ty), transportation network and origin-destination attributes (such as shipment origin-destination, } \\
\text { distance, ratio of highway and railway miles in origin and in destination), others (such as service } \\
\text { reliability, service frequency, loss and damage, shipper's characteristics) }\end{array}$ \\
\hline Kagnicioglu [28] & cost, quality of supply, quality of services \\
\hline Huang and Keskar [32] & cost, quality, timely delivery, flexibility \\
\hline Kannan and Tan [34] & quality, price, response, additional services \\
\hline Kumru and Kumru [39] & cost, speed, safety, accessibility, reliability, environmental friendliness, flexibility of transportation \\
\hline Shen et al. [40] & $\begin{array}{l}\text { reliability during transport, capacity, quality of service, transportation quickness, flexibility of } \\
\text { operation }\end{array}$ \\
\hline Ozcan and Ahiskali [41] & $\begin{array}{l}\text { delay rate, error rate, documentability, service quality, service ability, green policy, operation } \\
\text { excellence }\end{array}$ \\
\hline Tuzkaya and Önüt [42] & flexibility, reliability, speed, traceability, costs, security problems, risk \\
\hline Toker and Görener [43] & $\begin{array}{l}\text { economic features, service features, costs, traceability, environmental impacts, reliability, flexibility, } \\
\text { speed }\end{array}$ \\
\hline Lee et al. [44] & transport distance, transport time, transport cost \\
\hline Kumru and Kumru [45] & cost, time, reliability, power requirement, accessibility, product protection \\
\hline Moon et al. [46] & transport distance, transport time, transport cost, transport service, security, awareness \\
\hline Rahman and Pereda [47] & transport time, cost, reliability, security \\
\hline Pham et al. [48] & transportation time, transportation cost, reliability, route properties, storage cost \\
\hline Chen et al. [49] & transport cost, shipping time, delivery time, supply price, cost \\
\hline Belošević et al. [50] & service quality, reliability, transportation policy, economic impacts, environmental impacts \\
\hline
\end{tabular}

Table 2 - Matrix of weights assigned to each criterion by $r^{\text {th }}$ experts

\begin{tabular}{|c|l|l|l|l|l||}
\hline Criterion & Expert $_{1}$ & Expert $_{2}$ & $\ldots$ & Expert $_{r-1}$ & Expert $_{r}$ \\
\hline \hline $\mathrm{C}_{1}^{\mathrm{TM}}$ & & & & & \\
\hline $\mathrm{C}_{2}^{\mathrm{TM}}$ & & & & & \\
\hline$\cdots$ & & & & & \\
\hline $\mathrm{C}_{k-1}^{\mathrm{TM}}$ & & & & & \\
\hline $\mathrm{C}_{k}^{\mathrm{TM}}$ & & & & & \\
\hline
\end{tabular}

Table 3 - Matrix of weights for each p transport modes due to each $k$ criteria

\begin{tabular}{|c|l|l|l|l|l||}
\hline Criterion & $\mathrm{C}_{1}^{\mathrm{TM}}$ & $\mathrm{C}_{2}^{\mathrm{TM}}$ & $\cdots$ & $\mathrm{C}_{k-1}^{\mathrm{TM}}$ & $\mathrm{C}_{k}^{\mathrm{TM}}$ \\
\hline \hline $\mathrm{TM}_{1}$ & & & & & \\
\hline $\mathrm{TM}_{2}$ & & & & & \\
\hline$\cdots$ & & & & & \\
\hline $\mathrm{TM}_{p-1}$ & & & & & \\
\hline $\mathrm{TM} p$ & & & & & \\
\hline
\end{tabular}


From those calculations suitable transport mode can be chosen. Suitable transport mode is one whose aggregated weight $w D_{i}^{\mathrm{TM}}$ has the greatest value of the aggregated weight vector $w D^{\mathrm{TM}}$ (Equation 15).

$$
M A X w D_{i}^{\mathrm{TM}}=\max \left\{w D_{1}^{\mathrm{TM}}, w D_{2}^{\mathrm{TM}}, \ldots, w D_{p}^{\mathrm{TM}}\right\}
$$

Equation 15 shows that, from the considered transport mode on the basis of selected criteria and the AHP method, most suitable transport mode is the one which has the highest value of the aggregated weight vector $w D^{\mathrm{TM}}$.

\section{APPLICATION OF THE PROPOSED MODEL}

This chapter presents the application of the proposed model on an example, which deals with the selection of the mode of transport within the distribution logistics in the Slovak refinery company.
The company needs to select the most suitable mode of transport for a specific transport requirement on the basis of selected criteria by well-founded experts (Figure 2). Experts from the logistic department of the company have selected and specified (by brainstorming) the following six most important criteria from a list of possible criteria (Table 1):

Transport price $\left(\mathrm{C}_{1}^{\mathrm{TM}}\right)$ - Average price over 12 months per transported tonnes per kilometre of transport distance. The price consists of the transport of motor fuels from the refinery to the customer.

Average transport time $\left(\mathrm{C}_{2}^{\mathrm{TM}}\right)$ - Average transport time over 12 months from dispatched from the refinery to delivery to the customer.

Transported quantity $\left(\mathrm{C}_{3}^{\mathrm{TM}}\right)$ - Average transported quantity in transport units: road tank car, rail tank car, river barge.

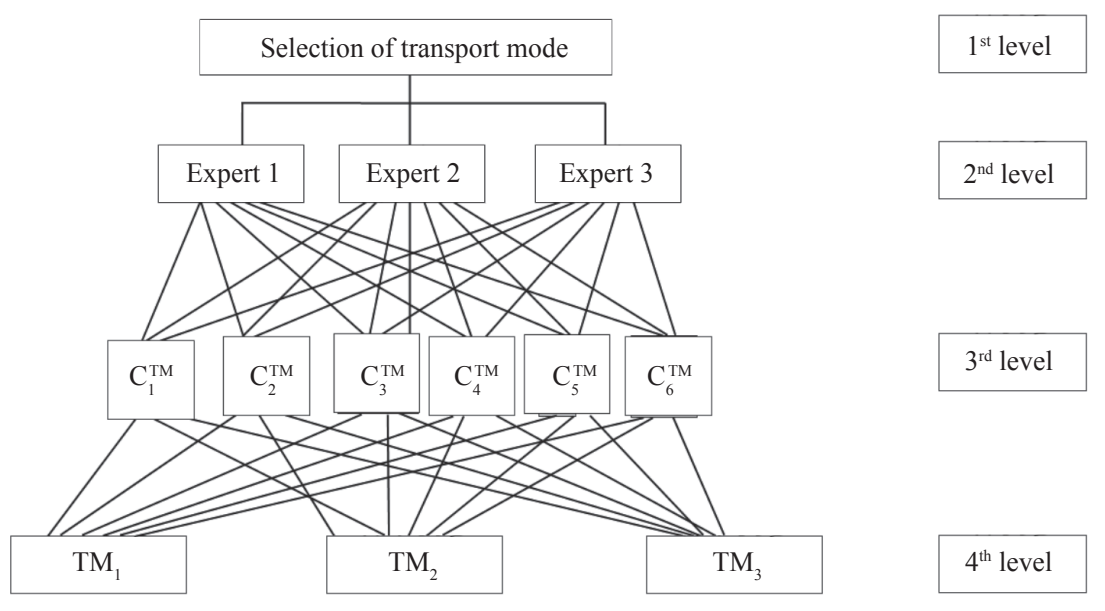

Figure 2 - Use of AHP method - decision problem of selection of transport mode

Table 4 - The criteria matrix for selection of transport mode

\begin{tabular}{||c|c|c|c|c|c|c|}
\hline & $\mathrm{C}_{1}^{\mathrm{TM}}$ & $\mathrm{C}_{2}^{\mathrm{TM}}$ & $\mathrm{C}_{3}^{\mathrm{TM}}$ & $\mathrm{C}_{4}^{\mathrm{TM}}$ & $\mathrm{C}_{5}^{\mathrm{TM}}$ & $\mathrm{C}_{6}^{\mathrm{TM}}$ \\
\hline \hline $\mathrm{TM}_{1}$ & $0.15 \mathrm{EUR} / \mathrm{t}$ & 12 hours & $1000 \mathrm{t}$ & 0.91 & 1.0 & $0.010 \mathrm{EUR} / \mathrm{t}$ \\
\hline $\mathrm{TM}_{2}$ & $0.12 \mathrm{EUR} / \mathrm{t}$ & 6 hours & $24 \mathrm{t}$ & 0.73 & 52.4 & $0.005 \mathrm{EUR} / \mathrm{t}$ \\
\hline $\mathrm{TM}_{3}$ & $0.10 \mathrm{EUR} / \mathrm{t}$ & 24 hours & $2000 \mathrm{t}$ & 0.65 & 27.2 & $0.020 \mathrm{EUR} / \mathrm{t}$ \\
\hline
\end{tabular}

$T M_{1}$ - rail transport, $T M_{2}$ - road transport, $T M_{3}$ - water transport

Table 5 - Filled-in matrix of priority weights assigned to each criterion by one expert

\begin{tabular}{|c|c|c|c|c|c|c|}
\hline $\begin{array}{l}\text { Selection of transport } \\
\text { mode }\end{array}$ & $\begin{array}{c}\mathrm{C}_{1}^{\mathrm{TM}} \\
\text { Transport } \\
\text { price }\end{array}$ & $\begin{array}{c}\mathrm{C}_{2}^{\mathrm{TM}} \\
\text { Average } \\
\text { transport time }\end{array}$ & $\begin{array}{c}\mathrm{C}_{3}^{\mathrm{TM}} \\
\text { Transported } \\
\text { quantity } \\
\end{array}$ & $\begin{array}{c}\mathrm{C}_{4}^{\mathrm{TM}} \\
\text { Transport } \\
\text { reliability }\end{array}$ & $\begin{array}{c}\mathrm{C}_{5}^{\mathrm{TM}} \\
\text { Ecology }\left(\mathrm{CO}_{2}\right) \\
\text { per transported ton }\end{array}$ & $\begin{array}{c}\mathrm{C}_{6}^{\mathrm{TM}} \\
\text { First and last } \\
\text { mile }\end{array}$ \\
\hline Transport price & 1 & 4 & 5 & 3 & 8 & 2 \\
\hline $\begin{array}{c}\text { Average transport } \\
\text { time }\end{array}$ & $1 / 4$ & 1 & $1 / 5$ & 4 & 3 & 5 \\
\hline Transported quantity & $1 / 5$ & 5 & 1 & 3 & 2 & 4 \\
\hline Transport reliability & $1 / 3$ & $1 / 4$ & $1 / 3$ & 1 & 6 & 2 \\
\hline $\begin{array}{l}\text { Ecology }\left(\mathrm{CO}_{2}\right) \text { per } \\
\text { transported ton }\end{array}$ & $1 / 8$ & $1 / 3$ & $1 / 2$ & $1 / 6$ & 1 & $1 / 4$ \\
\hline First and last mile & $1 / 2$ & $1 / 5$ & $1 / 4$ & $1 / 2$ & 4 & 1 \\
\hline
\end{tabular}


Hruška R, et al. Selection of the Transport Mode Using the AHP Method Within Distribution Logistics of Motor Fuels

Table 6-Matrix of criteria weights assigned by experts

\begin{tabular}{||c|c|c|c||}
\hline $\begin{array}{c}\text { Selection of } \\
\text { transport mode }\end{array}$ & Expert $_{1}$ & Expert $_{2}$ & Expert $_{3}$ \\
\hline \hline $\mathrm{C}_{1}^{\mathrm{TM}}$ & 0.4137 & 0.4115 & 0.4393 \\
\hline $\mathrm{C}_{2}^{\mathrm{TM}}$ & 0.1582 & 0.1536 & 0.1603 \\
\hline $\mathrm{C}_{3}^{\mathrm{TM}}$ & 0.2237 & 0.2326 & 0.2304 \\
\hline $\mathrm{C}_{4}^{\mathrm{TM}}$ & 0.1093 & 0.1155 & 0.0901 \\
\hline $\mathrm{C}_{5}^{\mathrm{TM}}$ & 0.0406 & 0.0318 & 0.0283 \\
\hline $\mathrm{C}_{6}^{\mathrm{TM}}$ & 0.0545 & 0.0551 & 0.0517 \\
\hline
\end{tabular}

Transport reliability $\left(\mathrm{C}_{4}^{\mathrm{TM}}\right)$ - Reliability of the transport is defined by the number of transports delivered on time, whereby $100 \%$ is full reliability.

Ecology $\left(\mathrm{CO}_{2}\right)$ per transported tonne $\left(\mathrm{C}_{5}^{\mathrm{TM}}\right)-$ Ecology $\left(\mathrm{CO}_{2}\right)$ per transported tonne represents the percentage of $\mathrm{CO}_{2}$ produced per tonne-kilometre.

First and last mile $\left(\mathrm{C}_{6}^{\mathrm{TM}}\right)$ - First and last mile represent the operating and technical costs of transportation motor fuels from production to the transport mean and from the transport mean to the final customer (loading, unloading, shunting...).

Carriers have been asked to send their offer according to the identified criteria. The company has the opportunity to use three different modes of transport for a given transport requirement (Table 4). Three well-founded experts from the field and from the company were asked to compare the identified criteria and evaluate their relationship. Based on this information, it was possible to fill in the matrix of criteria (Table 5).

Furthermore, the weight of each criterion in each level was determined. This is illustrated in Table 5 in the form of a filled matrix by one well-founded expert. Each well-founded expert filled in this table according to their expertise. There were three experts and they were equally well-founded, which implies that the weight of each expert corresponded to $1 / 3$. According to Equation 1, it can be described as a weight vector:

$v^{\text {experts }}=\left(v_{1}, v_{2}, \ldots, v_{r}\right)=(1 / 3 ; 1 / 3 ; 1 / 3)$

Based on these results, Table 6 shows the matrix of criteria weights assigned by all experts.

Table 7 shows the weights of the individual transport modes with relation to each criterion $\mathrm{C}_{1}^{\mathrm{TM}}-\mathrm{C}_{6}^{\mathrm{TM}}$.

The aggregated weight for each criterion was calculated according to Equation 11, and according to Equation 12 the aggregated weights of criteria can be written in the aggregated weight vector:
Table 7 - Matrix of weight for three possible transport modes due to criterion $C_{1}^{T M}-C_{6}^{T M}$

\begin{tabular}{|c|c|c|c|c|c|c|}
\hline $\mathrm{C}_{1}^{\mathrm{TM}}$ & $\mathrm{TM}_{1}$ & $\mathrm{TM}_{2}$ & $\mathrm{TM}_{3}$ & $s_{i}=\prod_{j=1}^{n} s_{i j}$ & $R_{i}=\sqrt[k]{s_{i}}$ & $v_{i}=\frac{R_{i}}{\sum_{i=1}^{k} R_{i}}$ \\
\hline $\mathrm{TM}_{1}$ & 1 & $1 / 4$ & $1 / 6$ & 15.0000 & 2.4662 & 0.6307 \\
\hline $\mathrm{TM}_{2}$ & 4 & 1 & 5 & 1.2000 & 1.0627 & 0.2717 \\
\hline $\mathrm{TM}_{3}$ & 6 & 5 & 1 & 0.0556 & 0.3816 & 0.0976 \\
\hline & & & & $\sum_{i=1}^{k} R_{i}$ & 4,3822 & 1.0000 \\
\hline
\end{tabular}

\begin{tabular}{|c|c|c|c|c|c|c|}
\hline $\mathrm{C}_{2}^{\mathrm{TM}}$ & $\mathrm{TM}_{1}$ & $\mathrm{TM}_{2}$ & $\mathrm{TM}_{3}$ & $s_{i}=\prod_{j=1}^{k} s_{i}$ & $R_{i}=\sqrt[k]{s_{i}}$ & $v_{i}=\frac{R_{i}}{\sum_{i=1}^{k} R_{i}}$ \\
\hline $\mathrm{TM}_{1}$ & 1 & $1 / 3$ & 3 & 1.0000 & 1.0000 & 0.2499 \\
\hline $\mathrm{TM}_{2}$ & 3 & 1 & 6 & 18.0000 & 2.6207 & 0.6548 \\
\hline $\mathrm{TM}_{3}$ & $1 / 3$ & $1 / 6$ & 1 & 0.0556 & 0.3816 & 0.0953 \\
\hline & & & & $\sum_{i=1}^{k} R_{i}$ & 4.0023 & 1.0000 \\
\hline
\end{tabular}

\begin{tabular}{||c|c|c|c|c|c|c||}
\hline \hline $\mathrm{C}_{3}^{\mathrm{TM}}$ & $\mathrm{TM}_{1}$ & $\mathrm{TM}_{2}$ & $\mathrm{TM}_{3}$ & $s_{i}=\prod_{j=1}^{k} s_{i j}$ & $R_{i}=\sqrt[k]{s_{i}}$ & $v_{i}=\frac{R_{i}}{\sum_{i=1}^{k} R_{i}}$ \\
\hline $\mathrm{TM}_{1}$ & 1 & 5 & $1 / 4$ & 1.2500 & 1.0772 & 0.2370 \\
\hline $\mathrm{TM}_{2}$ & $1 / 5$ & 1 & $1 / 8$ & 0.0250 & 0.2924 & 0.0643 \\
\hline $\mathrm{TM}_{3}$ & 4 & 8 & 1 & 32.0000 & 3.1748 & 0.6986 \\
\hline
\end{tabular}

\begin{tabular}{|l|c|c|c|c|c|c|}
\hline \hline $\mathrm{C}_{4}^{\mathrm{TM}}$ & $\mathrm{TM}_{1}$ & $\mathrm{TM}_{2}$ & $\mathrm{TM}_{3}$ & $s_{i}=\prod_{j=1}^{k} s_{i j}$ & $R_{i}=\sqrt[k]{s_{i}}$ & $v_{i}=\frac{R_{i}}{\sum_{i=1}^{k} R_{i}}$ \\
\hline $\mathrm{TM}_{1}$ & 1 & 6 & 4 & 24.0000 & 2.8845 & 0.6878 \\
\hline $\mathrm{TM}_{2}$ & $1 / 6$ & 1 & 5 & 0.8333 & 0.9410 & 0.2244 \\
\hline $\mathrm{TM}_{3}$ & $1 / 4$ & $1 / 5$ & 1 & 0.0500 & 0.3684 & 0.0878 \\
\hline
\end{tabular}

\begin{tabular}{||c|c|c|c|c|c|c||}
\hline \hline $\mathrm{C}_{5}^{\mathrm{TM}}$ & $\mathrm{TM}_{1}$ & $\mathrm{TM}_{2}$ & $\mathrm{TM}_{3}$ & $s_{i}=\prod_{j=1}^{k} s_{i j}$ & $R_{i}=\sqrt[k]{s_{i}}$ & $v_{i}=\frac{R_{i}}{\sum_{i=1}^{k} R_{i}}$ \\
\hline $\mathrm{TM}_{1}$ & 1 & 6 & 8 & 48.0000 & 3.6342 & 0.7536 \\
\hline $\mathrm{TM}_{2}$ & $1 / 6$ & 1 & 4 & 0.6667 & 0.8736 & 0.1811 \\
\hline $\mathrm{TM}_{3}$ & $1 / 8$ & $1 / 4$ & 1 & 0.0313 & 0.3150 & 0.0653 \\
\hline \multicolumn{1}{l}{} & $\sum_{i=1}^{k} R_{i}$ & 4.8228 & 1.0000 \\
\hline
\end{tabular}

\begin{tabular}{|l|c|c|c|c|c|c||}
\hline \hline $\mathrm{C}_{6}^{\mathrm{TM}}$ & $\mathrm{TM}_{1}$ & $\mathrm{TM}_{2}$ & $\mathrm{TM}_{3}$ & $s_{i}=\prod_{j=1}^{k} s_{i j}$ & $R_{i}=\sqrt[k]{s_{i}}$ & $v_{i}=\frac{R_{i}}{\sum_{i=1}^{k} R_{i}}$ \\
\hline $\mathrm{TM}_{1}$ & 1 & 3 & 6 & 18.0000 & 2.6207 & 0.6667 \\
\hline $\mathrm{TM}_{2}$ & $1 / 3$ & 1 & $1 / 4$ & 0.0833 & 0.4368 & 0.1111 \\
\hline $\mathrm{TM}_{3}$ & $1 / 6$ & 4 & 1 & 0.6667 & 0.8736 & 0.2222 \\
\hline
\end{tabular}


Hruška R, et al. Selection of the Transport Mode Using the AHP Method Within Distribution Logistics of Motor Fuels

Table 8-Matrix of weight of each p transport mode by each $C^{T M}$ criteria

\begin{tabular}{|c||c|c|c|c|c|c||}
\hline $\begin{array}{c}\text { Selection of } \\
\text { transport mode }\end{array}$ & $\mathrm{C}_{1}^{\mathrm{TM}}$ & $\mathrm{C}_{2}^{\mathrm{TM}}$ & $\mathrm{C}_{3}^{\mathrm{TM}}$ & $\mathrm{C}_{4}^{\mathrm{TM}}$ & $\mathrm{C}_{5}^{\mathrm{TM}}$ & $\mathrm{C}_{6}^{\mathrm{TM}}$ \\
\hline $\mathrm{TM}_{1}$ & 0.6307 & 0.2499 & 0.2370 & 0.6878 & 0.7536 & 0.6667 \\
\hline $\mathrm{TM}_{2}$ & 0.2717 & 0.6548 & 0.0643 & 0.2244 & 0.1811 & 0.1111 \\
\hline $\mathrm{TM}_{3}$ & 0.0976 & 0.0953 & 0.6986 & 0.0878 & 0.0653 & 0.2222 \\
\hline
\end{tabular}

$w K^{\mathrm{TM}}=(0.4172 ; 0.1557 ; 0.2266 ; 0.1039 ; 0.0332 ; 0.0532)$

Furthermore, $p$ transport modes were compared by Saaty's method for planning each criterion (Table 8).

The aggregated weight for each transport mode was calculated according to Equation 13, and according to Equation 14 the aggregated weights of transport modes can be written in the aggregated weight vector as follows:

$w D^{\mathrm{TM}}=(0.3654 ; 0.3218 ; 0.3126)$

The suitable transport mode for the company is chosen on the basis of Equation 15:

$M A X w D_{i}^{\mathrm{TM}}=\max \{0.3654 ; 0.3218 ; 0.3126\}$

$M A X w D_{i}^{\mathrm{TM}}=0.3654$

Equation 15 shows that of the three transport modes considered, based on the identified criteria and the AHP method, $\mathrm{D}_{1}$ is the most suitable transport mode for the real transport requirement because it has the highest value of the aggregated weighted vector.

\section{DISCUSSION}

Based on the applied model, it was found that under the given transport requirements and offers (Table 4), it is advantageous to choose rail transport.

The aggregated weights of transport modes do not differ much from each other. The model is able to evaluate with high accuracy the different solution variants (in this case transport modes) which implies that the applied AHP method is based on the use of the Saaty's method, which is based on pairwise comparison and allows using the Saaty's scale (Equation 3) to express more accurately the degree of preferences between criteria and alternatives (in this case transport modes). A significant advantage of the proposed model is that it can be easily modified in its parameters. For example, the number of experts and the number of criteria can be modified. We must not forget that in case of modification we have to modify the calculations adequately.
This paper upscales on general articles focusing on transport mode selection, for example [26, 27, $42,45]$, because it is very narrowly and specifically focused on the refining industry. According to the literature review, the other authors have not yet addressed the issue of transport mode selection using the AHP method in the context of distribution logistics of motor fuels. This identified gap has therefore been filled.

\section{CONCLUSION}

The main contribution of this article was a literature review in the field of criteria influencing the choice of transport mode within the distribution logistics of motor fuels. The article also contains the proposal of a decision-making tool for selection of the transport mode using the AHP method within distribution logistics of motor fuels. This means that the aim of the paper has been achieved.

Many researchers and practitioners have focused their work and attention on the choice of mode of transport in supply chain management and have used a wide range of scientific and technical methods to increase the efficiency and flexibility of supply networks. There are various approaches available for choosing a mode of transport.

Each production company that is part of the supply chain uses multiple modes of transport. The main problem is the decision to choose the most suitable mode of transport for specific transport requirement, because it is a complex and complicated decision-making problem with many input variables. When choosing the mode of transport, the company must take into account all the important factors that have a significant impact on this decision. In this paper, the AHP method was used as one of the possible methods of selecting the transport mode for a specific transport requirement. The next main contribution of this paper was the identification of important criteria in the process of selecting a suitable mode of transport. The limitations of the proposed model are in the limited number of criteria. If we used more than ten criteria, the expert would have a 
problem with the correct fill-in of the Saaty matrix in the sense of observing right differences between the criteria. Then, a multicriteria decision-making model was developed for the evaluation and selection of modes of transport using the AHP method. The developed model was then applied and verified in the form of a case study on a real example from business practice. The added value of the model is that it represents a useful decision support tool for selection of the transport mode. Possibilities for further development of the model are modifications of the used criteria in accordance with the developments within the refining industry (e.g. due to the impact of the COVID-19 pandemic or the global economic recession). The AHP method was used because it is the most frequently used method, but it also has many weaknesses. One possible way to eliminate the weakness of the AHP method is by using the ANP (Analytic Network Process) method. The ANP method is a network generalisation of the AHP method. The ANP method compared to the AHP method allows to include all possible interdependencies and feedback in the system.

\section{ACKNOWLEDGEMENT}

This paper is published within the solution of the scientific research project of the University of Pardubice no.SGS_2021_018. The authors are grateful for their support.

Ing. ROMAN HRUŠKA, Ph.D. ${ }^{1}$

E-mail: roman.hruska@upce.cz

Ing. MATEJ KMETÍK ${ }^{1}$

E-mail: matej.kmetik@student.upce.cz

Ing. JAN CHOCHOLÁČ, Ph.D. ${ }^{1}$

E-mail: jan.chocholac@upce.cz

1 Univerzita Pardubice, Dopravní fakulta Jana Pernera

Katedra dopravního managementu, marketingu a logistiky

Studentská 95, 53210 Pardubice, Česká republika

\section{VÝBĚR DRUHU DOPRAVY POUŽITÍM METO- DY AHP V RÁMCI DISTRIBUČNÍ LOGISTIKY MOTOROVÝCH PALIV}

\section{ABSTRAKT}

Abychom si udrželi konkurenceschopnost a mohli reagovat na rychle se ménicí trhy, musime na dnešnim globálním trhu zvýšit flexibilitu. V tomto ohledu je výběr vhodného druhu dopravy jednou z nejdůležitějšich funkcí, kterou musi logistika plnit. Výběr vhodného druhu dopravy je multikriteriální problém zahrnujicí jak kvantitativní, tak kvalitativni kritéria. Tento článek se zabývá výběrem druhu dopravy pomoci metody analytického hierarchického procesu (AHP). AHP je metoda rozkladu složiténestrukturovanésituace na jednodǔšsisložky, která vytvárí hierarchický systémový problém. Tento článek popisuje obecný model výbèru vhodného druhu dopravy pomoci AHP včetně jeho aplikace ve výrobni společnosti, která vybirá vhodný druh dopravy ze tři možných druhủ dopravy. Cílem tohoto článku je vytvořit užitečný nástroj pro podporu rozhodování při výbéru druhu dopravy pomocí metody AHP v rámci distribuční logistiky motorových paliv. Tento nástroj pomáhá společnostem správně rozhodnout o výběru dopravního módu tím, že zohledñuje rozdílnou důležitost jednotlivých kritérií, která ovlivňuji rozhodovaci proces.

\section{KLÍČOVÁ SLOVA}

doprava; distribuční logistika; metoda AHP; rozhodování; druh dopravy.

\section{REFERENCES}

[1] Harks T, et al. An integrated approach to tactical transportation planning in logistics networks. Transportation Science. 2016;50(2): 439-460. DOI: 10.1287/ trsc.2014.0541

[2] Kechagias EP, et al. An application of an urban freight transportation system for reduced environmental emissions. Systems. 2020;8(4): 49. DOI: 10.3390/systems 8040049

[3] Galkin A, et al. Planning the rational freight vehicle fleet utilization considering the season temperature factor. Sustainability. 2021;13(7): 3782. DOI: 10.3390/ su13073782

[4] Calabrò G, Torrisi V, Inturri G, Ignaccolo M. Improving inbound logistic planning for large-scale real-world routing problems: A novel ant-colony simulation-based optimization. European Transport Research Review. 2020;12(1): 21. DOI: 10.1186/s12544-020-00409-7

[5] Ferrell W, Ellis K, Kaminsky P, Rainwaterd C. Horizontal collaboration: Opportunities for improved logistics planning. International Journal of Production Research. 2019;58(14): 4267-4284. DOI: 10.1080/ 00207543.2019 .1651457

[6] Roman C, Arencibia AI, Feo-Valero M. A latent class model with attribute cut-offs to analyse modal choice for freight transport. Transportation Research Part A Policy and Practice. 2017;102: 212-227. DOI: 10.1016/ j.tra.2016.10.020

[7] Kumarage AS. Urban traffic congestion: The problem \& solutions. Economic Review. 2004;1: 2-8. Available from: https://www.researchgate.net/publication/311375042 urban_traffic_congestion_the_problemsolutions [Accessed 4th May 2021]

[8] Bjorgen A, Seter H, Kristensen T, Pitera K. The potential for coordinated logistics planning at the local level: A Norwegian in-depth study of public and private stakeholders. Journal of Transport Geography. 2019;76: 3441. DOI: $10.1016 /$ j.jtrangeo.2019.02.010

[9] He Z. The challenges in sustainability of urban freight network design and distribution innovations: A systematic literature review. International Journal of Physical 
Distribution \& Logistics Management. 2020;50(6): 601640. DOI: 10.1108/IJPDLM-05-2019-0154

[10] Hugos M. Zarzadzanie Ean'cuchem Dostaw. Podstawy. Gliwice: Wydawnictwo Helion; 2011.

[11] Kaszubowski D. A method for the evaluation of urban freight transport models as a tool for improving the delivery of sustainable urban transport policy. Sustainability. 2019;11(6): 1535. DOI: 10.3390/su11061535

[12] Sert E, et al. Freight time and cost optimization in complex logistics networks. Complexity. 2020; 2189275. DOI: $10.1155 / 2020 / 2189275$

[13] Kechagias EP, Gayialis SP, Konstantakopoulos GD, Papadopoulos GA. An application of a multi-criteria approach for the development of a process reference model for supply chain operations. Sustainability. 2020;12(14): 5791. DOI: $10.3390 /$ su12145791

[14] Konstantakopoulos GD, et al. A Multiobjective Large neighborhood search metaheuristic for the vehicle routing problem with time windows. Algorithms. 2020;13(10): 243. DOI: $10.3390 / \mathrm{a} 13100243$

[15] Aprile D, et al. Logistics optimization: Vehicle routing with loading constraints. In: ICPR-19, The development of collaborative production and Service Systems in Emergent Economies, $19^{\text {th }}$ International Conference on Production Research, 29 July - 2 Aug 2007. Valparaiso, CL. Available from: https://citeseerx.ist.psu.edu/ viewdoc/download?doi=10.1.1.386.9367\&rep=rep1\&type $=$ pdf [Accessed 7th May 2021].

[16] Jensen AF, et al. A disaggregate freight transport chain choice model for Europe. Transportation Research Part E-Logistics and Transportation Review. 2019;121: 4362. DOI: 10.1016/j.tre.2018.10.004

[17] Abate M, Vierth I, Karlsson R, de Jong G, Baak J. A disaggregate stochastic freight transport model for Sweden. Transportation. 2019;46(3): 671-696. DOI: 10.1007/ s11116-018-9856-9

[18] Abdelwahab WM. Elasticities of mode choice probabilities and market elasticities of demand: Evidence from a simultaneous mode choice shipment-size freight transport model. Transportation Research Part E-Logistics and Transportation Review. 1998;34(4): 257-266. DOI: 10.1016/S1366-5545(98)00014-3

[19] Outwater M, et al. Tour based and supply chain modeling for freight: Integrated model demonstration in Chicago. Transportation Letters - The International Journal of Transportation Research. 2013;5(2): 55-66. DOI: 10.1179/1942786713Z.0000000009

[20] Beuthe M, Jourquin B, Geerts JF, Ha C. Freight transportation demand elasticities: A geographic multimodal transportation network analysis. Transportation Research Part E - Logistics and Transportation Review. 2001;37(4): 253266. DOI: $10.1016 / \mathrm{S} 1366-5545(00) 00022-3$

[21] Feo-Valero M, Garcia-Menendez L, Saez-Carramolino L, Furio-Prunonosa S. The importance of the inland leg of containerised maritime shipments: An analysis of modal choice determinants in Spain. Transportation Research Part E - Logistics and Transportation Review. 2011;47(4): 446-460. DOI: 10.1016/j.tre.2010.11.011

[22] De Jong G, et al. Distribution and modal split models for freight transport in the Netherlands. In: ETC 2011: European Transport Conference, 10-12 October 2011,
Glasgow, UK. Available from: https://repository.tudelft. $\mathrm{nl} /$ islandora/object/uuid:1cb838c0-3454-48bb-9290$84 \mathrm{dc} 0 \mathrm{~b} 7 \mathrm{cb} 219 /$ datastream/OBJ/download [Accessed 9th May 2021].

[23] Guo Z, et al. Green transportation scheduling with pickup time and transport mode selections using a novel multi-objective memetic optimization approach. Transportation Research Part D - Transport and Environment. 2018;60: 137-152. DOI: 10.1016/j.trd.2016.02.003

[24] Hoen KMR, Tan T, Fransoo JC, van Houtum GJ. Effect of carbon emission regulations on transport mode selection under stochastic demand. Flexible Services and Manufacturing Journal. 2014;26(1-2): 170-195. DOI: 10.1007/s10696-012-9151-6

[25] Blauwens G, et al. Towards a modal shift in freight transport? A business logistics analysis of some policy measures. Transport Reviews. 2006;26(2): 239-251. DOI: 10.1080/01441640500335565

[26] Kiesmuller GP, de Kok AG, Fransoo JC. Transportation mode selection with positive manufacturing lead time. Transportation Research Part E - Logistics and Transportation Review. 2005;41(6): 511-530. DOI: 10.1016/j. tre.2005.07.003

[27] Keya N, Anowar S, Eluru N. Freight mode choice: A regret minimization and utility maximization based hybrid model. Transportation Research Record. 2018;2672(9): 107-119. DOI: $10.1177 / 0361198118782256$

[28] Kagnicioglu CH. A fuzzy multiobjective programming approach for supplier selection in a supply chain. The Business Review. 2006;6(1): 107-115.

[29] Lasch R, Janker CG. Supplier selection and controlling using multivariate analysis. International Journal of Physical Distribution \& Logistics Management. 2005;35(6): 409-425. DOI: $10.1108 / 09600030510611648$

[30] Ghodsypour SH, O'Brien C. The total cost of logistics in supplier selection, under conditions of multiple sourcing, multiple criteria and capacity constraint. International Journal of Production Economics. 2001;73(1): 15-27. DOI: 10.1016/S0925-5273(01)00093-7

[31] Lin R-H. Potential use of FP-growth algorithm for identifying competitive suppliers in SCM. Journal of the Operational Research Society. 2009;60(8): 1135-1141. DOI: $10.1057 /$ jors.2008.157

[32] Huang SH, Keskar H. Comprehensive and configurable metrics for supplier selection. International Journal of Production Economics. 2007;105(2): 510-523. DOI: 10.1016/j.ijpe.2006.04.020

[33] Hsu C-C, Kannan VR, Leong GK, Tan K-C. Supplier selection construct: Instrument development and validation. International Journal of Logistics Management. 2006;17(2):213-239. DOI: 10.1108/09574090610689961

[34] Kannan VR, Tan KC. Supplier selection and assessment: Their impact on business performance. Journal of Supply Chain Management. 2002;38(3): 11-21. DOI: 10.1111/j.1745-493X.2002.tb00139.x

[35] Weber CA, Current JR, Benton WC. Vendor selection criteria and methods. European Journal of Operational Research. 1991;50(1): 2-18. DOI: 10.1016/03772217(91)90033-R

[36] Barbarosoglu G, Yazgac T. An application of the analytic hierarchy process to the supplier selection problem. Pro- 
duction and Inventory Management Journal. 1997;38(1): 14-21.

[37] Morlacchi P. SMEs in supply chain: A supplier evaluation model and some empirical results. In: Research Perspectives in Purchasing and Supply Chain Management: Selected Papers of the Third and Fourth IFPMM Summer Schools. IFPMM Summer School Secretariat, Salzburg; 1999. p. 77-92.

[38] Kumar M, Vrat P, Shankar R. A fuzzy goal programming approach for vendor selection problem in a supply chain. Computers \& Industrial Engineering. 2004;46(1): 69-85. DOI: 10.1016/j.cie.2003.09.010

[39] Kumru M, Kumru PY. Analytic hierarchy process application in selecting the mode of transport for a logistics company. Journal of Advanced Transportation. 2014;48(8): 974-999. DOI: 10.1002/atr.1240

[40] Shen L, Mathiyazhagan K, Kannan D, Ying W. Study on analysing the criteria's for selection of shipping carriers in Chinese shipping market using analytical hierarchy process. International Journal of Shipping and Transport Logistics. 2015;7(6): 742-757. DOI: 10.1504/ IJSTL.2015.072685

[41] Ozcan E, Ahiskali M. 3PL Service provider selection with a goal programming model supported with multicriteria decision making approaches. Gazi University Journal of Science. 2020;33(2): 413-427. DOI: 10.35378/ gujs. 552070

[42] Tuzkaya UR, Önüt S. A fuzzy analytic network process based approach to transportation-mode selection between Turkey and Germany: A case study. Information Sciences. 2008;178(15): 3133-3146. DOI: 10.1016/ j.ins.2008.03.015

[43] Toker K, Görener A. Lojistik yönetimi kapsaminda ulaştirma modunun seçimi: Tekstil sektöründe bir uygulama. İsletme Fakültesi İsletme İktisadi Enstitüsü Yönetim Dergisi. 2013;24(74): 16-37.

[44] Lee EK, Kim DJ, Moon DS. A study on competitiveness analysis of international transportation routes between Korea and EU With Entropy-TOPSIS. The Journal of
Productivity. 2013;27(4): 123-149. DOI: 10.15843/KPAPR.27.4.201312.123

[45] Kumru M, Kumru PY. Analytic hierarchy process application in selecting the mode of transport for a logistics company. Journal of Advanced Transportation. 2014;48(8): 974-999. DOI: 10.1002/atr.1240

[46] Moon DS, Kim DJ, Lee EK. A study on competitiveness of sea transport by comparing international transport routes between Korea and EU. The Asian Journal of Shipping and Logistics. 2015;31(1): 1-20. DOI: 10.1016/j.ajsl.2015.03.001

[47] Rahman MA, Pereda VA. Freight transport and logistics evaluation using entropy technique integrated to TOPSIS algorithm. In: Design Solutions for User-Centric Information Systems; 2017. DOI: 10.4018/978-1-5225-19447.ch004

[48] Pham T, Kim K, Yeo GT. The Panama Canal expansion and its impact on east-west liner shipping route selection. Sustainability. 2018;10(12): 1-16. DOI: 10.3390/ su10124353

[49] Chen HL, Shih SZ, Lirn TC. The study of grain importers transport mode choice behavior. International Symposium on Logistics Big Data Enabled Supply Chain Innovations, 8-11 July 2018, Bali, Indonesia; 2018.

[50] Belošević I, Kosijer M, Ivić M, Pavlović N. Group decision making process for early stage evaluations of infrastructure projects using extended VIKOR method under fuzzy environment. European Transport Research Review. 2018;10(2): 1-14. DOI: 10.1186/s12544-0180318-4

[51] Saaty TL. The Analytic Hierarchy Process. Pittsburgh, PA: RWS Publications; 1983.

[52] Gogus A. Brainstorming and learning: Encyclopedia of the sciences of learning. Springer; 2012. DOI: 10.1007/978-1-4419-1428-6_491

[53] Al-Samarraie H, Hurmuzan S. A review of brainstorming techniques in higher education. Thinking Skills and Creativity. 2018;27: 78-91. DOI: 10.1016/j.tsc.2017.12.002 